\title{
Neuropsychological Characteristics of Dyslexic Children
}

\section{Características Neuropsicológicas de Crianças com Dislexia}

\author{
Camila Cruz-Rodrigues ${ }^{*}, a, b$, Thaís Barbosa ${ }^{b}$ Carolina M. J. Toledo-Piza $^{b}$, \\ Mônica Carolina Miranda ${ }^{b} \&$ Orlando Francisco Amodeo Bueno ${ }^{b}$ \\ ${ }^{a}$ Universidade Presbiteriana Mackenzie, São Paulo, São Paulo, Brasil, \\ $\&{ }^{b}$ Universidade Federal de São Paulo, São Paulo, São Paulo, Brasil
}

\begin{abstract}
The aim of this study was to identify the neuropsychological characteristics of dyslexic children. Seventy-three children underwent neuropsychological assessment and were divided into two groups: a group with dyslexia (DG; $n=39$ ) and a control group (CG; $n=34$ ). A general linear model showed a significant difference between the groups regarding the following abilities: reading, writing and mathematics; forward and backward digit span tasks; semantic and phonological fluency; number of completed categories and total number of cards in the Wisconsin Cards Sorting Test; as well as right and left discrimination on self and on other. These results suggest impairment in executive functions, phonological working memory and semantic memory among dyslexic children, rather than impairment of just phonological abilities, as suggested in previous studies.

Keywords: Dyslexia, Wisconsin test, neuropsychological characteristics.
\end{abstract}

\begin{abstract}
Resumo
O objetivo deste trabalho foi identificar as características neuropsicológicas de crianças com dislexia. Foram incluídas 73 crianças divididas em dois grupos: um grupo composto por crianças disléxicas (GD; $n=39)$, e um grupo controle (GC; $n=34)$. A análise de modelo linear geral mostrou diferença significativa entre os grupos nas habilidades de leitura, escrita, matemática, dígitos ordem direta, dígitos ordem inversa, fluência semântica e fonológica, número de categorias e total de cartas do Teste de Classificação de Cartas de Wisconsin, discriminação direita e esquerda em si e no outro. Esses resultados demonstram que podem existir déficits nas funções executivas, memória operacional fonológica e memória semântica e não apenas nas habilidades fonológicas.

Palavras-chave: Dislexia, Wisconsin Teste, características neuropsicológicas.
\end{abstract}

\section{Neuropsychological Characteristics of Dyslexia}

Psychological studies on learning reinforce that learning development occurs through the interaction of genetic, biological, organic and environmental factors (Kaefer, 2006). Thus, it is crucial to investigate these aspects, which directly reflect a child's ability to learn, with a view to understanding the acquisition and development of specific learning abilities at school (e.g., reading, writing and mathematics abilities).

In Brazil, $30 \%$ to $40 \%$ of children attending initial school years present some sort of difficulty in learning processes. However, only, $3 \%$ to $5 \%$ of this group will fulfill criterias to be clinically diagnosed with a learning disability (LD; Ciasca, 2003). In the international literature, the prevalence rate of LDs varies from 5\% to 17\% (Bishop,

${ }^{*}$ Mailing Address: Centro de Ciencias Biológicas e da Saúde, Universidade Presbiteriana Mackenzie, Rua da Consolaçao, 896, Predio 38, Centro, São Paulo, SP, Brasil 01392-907. E-mail: camilacruzrodrigues@hotmail.com, barbosa_thais@hotmail.com, carolatp@hotmail.com, mirandambr@yahoo.com.br and ofabueno@gmail.com Acknowledgements: This research was supported by CNPq, CAPES and AFIP.
2006; Sally \& Shaywitz, 1998; Santos \& Navas, 2002) affecting $1-2.5 \%$ of the general population and $10-15 \%$ of school-aged children (Hendriksen et al., 2007).

For better understanding of this important developmental disorder, it is necessary to clarify that LDs differ from learning difficulties. The latter refers to academic difficulties derived from other conditions (e.g., environmental stress, or inappropriate methods of teaching), while the former is characterized by a difficulty in academic learning despite an appropriate level of intelligence and after the exclusion of other causes that justify difficulties presented (Ciasca, 2003). Therefore, "not all children presenting difficulties when learning how to read can be considered as having some type of reading and writing disabilities" (Santos \& Navas, 2002, p. 27). Definitions may vary slightly, since much controversy emerges regarding the underpinning processes and cognitive profile related to this disorder. Nevertheless, some factors are common elements within the various studies of LDs: heterogeneity, represented by the involvement of multiple domains; a constitutional (or neurobiological) nature; discrepancy between an individual's learning potential (or level of intelligence) and academic performance; the absence of 
primary problems (e.g., sensorial deficits, mental retardation, inadequate education) and lastly, an impact on an individual's school performance and/or daily activities.

Various other studies have also sought to identify factors and characteristics that may contribute to a precise diagnosis of specific reading disabilities (dyslexia). Among them, the presence of changes in oral language and cognitive abilities are exhaustively mentioned by different authors (Barbosa, Miranda, Santos, \& Bueno, 2009; Bishop \& Adams, 1990; Capellini \& Ciasca, 2000; Catts, 1993; Ciasca, 2003; Santos \& Navas, 2002).

In order to increase the overall knowledge on LDs, an interdisciplinary assessment aiming to exchange information between the medical, neuropsychological, phonological and educational fields is of utmost importance (Pestun, Ciasca, \& Gonçalves, 2002). More specifically, a neuropsychological assessment may contribute to the diagnosis of learning disorders, especially in helping to identify comorbidities and in defining differential diagnoses (Hendriksen et al., 2007). Neuropsychological characteristics observed within these patients also allow for the appropriate planning of interventions, as they provide us with a better understanding of abilities and difficulties associated with LDs (Salles \& Parente, 2006).

One of the main symptoms described in this population is a deficit in phonological abilities, however, other overlapping characteristics may also be observed. For instance, deficits in motor skills, attentional processes and impairment in auditory and visual processing may occur, according to previous studies (Ramus et al., 2003; Salles \& Parente, 2006). Salles and Parente (2006), investigated that third grade children with reading and writing problems, showed a delay in the development of phonological awareness (e.g., phonemic rhyme, alliteration, exclusion and subtraction tasks), phonological working memory (e.g., pseudoword repetition) and oral speech (e.g., story recall).

With regard to the assessment of intelligence level, Arduini, Capellini and Ciasca (2006) found a discrepancy between verbal (VIQ) and performance intelligence level (PIQ) among children with LDs. Such data corroborates with findings of Ingesson (2006) who, in reassessing dyslexic patients after an interval of 80 months, observed a reduction in their VIQ and an increase in their PIQ.

A study conducted by Kibby and Cohen (2008), examined specific cognitive functions of U.S dyslexic children. Finding indicated impairment in phonological working memory tasks (i.e., tasks requiring phonological decoding, such as the repetition of digits, sequences and word lists). However, no differences were observed in the development of episodic memory abilities (e.g., story recall tasks) or visual working memory capacities, despite their difficulty in verbal working memory tasks. Furthermore, Kibby and Cohen (2008) observed better performance of children with dyslexia on backward digit span tests, when compared to forward digit span tests, demonstrating impairment in their working memory but not in their central executive subsystem.
According to Baddeley's (2000) Working Memory Model, dyslexic children usually present impairment in tasks involving the phonological loop subcomponent although in most cases, their abilities involving the visuospatial sketchpad, central executive and/or episodic buffer subcomponents are preserved (Kibby \& Cohen, 2008; Kibby, Marks, Morgan, \& Long, 2004).

On the other hand, Maehler, Schuchardtand Hasselhorn (2008) found that dyslexic children present impairment in both the phonological loop and central executive subcomponents, while children with dyscalculia have deficits in the visuo-spatial sketchpad subcomponent. Their study further demonstrated that dyslexic children with a low IQ presented the same working memory impairment seen in those with an average or above average IQ, reinforcing the importance of discussing the level of intelligence -- measured through the Wechsler Intelligence Scale for Children (WISC) - among children with LDs (Maehler \& Schuchardt, 2009).

Accordingly, Kibby (1999, cited by Kibby \& Cohen, 2008) shows that verbal working memory, phonological awareness and verbal intelligence (VIQ) are involved in the decoding of pseudowords and that such abilities can affect language.

In cases of dyslexia, difficulties in the verbal manipulation of information may be a reflection of the predominantly phonological basis of the disorder (Salles \& Parente, 2006), but other alterations in cognitive operations may also be associated (Ramus et al., 2003). The heterogeneity that characterizes dyslexia emphasizes the profound importance of understanding the underlying neuropsychological characteristics of reading and writing abilities. Such understanding will contribute to the diagnosis of dyslexia, particularly with respect to the identification of comorbidities and in defining differential diagnoses (Salles \& Parente, 2006).

Therefore, the aim of this study was to to identify the neuropsychological characteristics of dyslexic children. As such, neuropsychological functions - intellectual level, memory, executive function, visuo-constructive ability, right-left discrimination and laterality abilities - of dyslexic children were compared to those of controls, with no history of dyslexia.

\section{Method}

\section{Subjects}

A total of 191 children participated in this study, from December 2005 to December 2009, composing the control (CG) and dyslexia group (DG).

The selection of volunteers for the research involved various stages. The DG was composed by children with learning complaints, who were referred to the Learning Disorder outpatient unit at the Centro Paulista de Neuropsicologia (CPN)/ Núcleo de Atendimento Neuropsicológico Infantil Interdisciplinar (NANI), São Paulo (SP), Brazil. 
Cruz-Rodrigues, C., Barbosa, T., Toledo-Piza, C. M. J., Miranda, M. C. \& Bueno, O. F. A. (2014). Neuropsychological Characteristics of Dyslexic Children.

Forty five children underwent an interdisciplinary assessment (with neuropsychology, psycho-educational, and speech-therapist specialists), of which 39 children met diagnostic criteria for Dyslexia according to DSM - IVTR norms (American Psychiatric Association, 2003) and composed the dyslexia group (DG). The inclusion criteria for the DG was: minimum of 8 years of age, average or above average level of intelligence (Full Scale Intelligence Quotient - FSIQ>80; Wechsler, 2002), 2-year delay in school performance (reading- School Performance Test - TDE; Stein, 1994).

The control group (CG) was paired to the DG according to age, gender, school type (public or private) and current school year. For such, 46 children, with average performance in reading and writing skills, were indicated by the school coordinators, and accepted to take part in the present project. All controls achieved an average or above average level of intelligence and school performance (reading, writing and mathematics) and did not present delay in neuropsychomotor development and/or behavioral complaints.

In both groups, children with signs of clinical, neurological or psychiatric diseases, as well as neuropsychomotor delay, intellectual disabilities, attention and hyperactivity deficit disorder (ADHD), or other development disorders were excluded.

\section{Procedure}

All participants (parents and/or legal guardians) authorized their child's participation through the signature of an informed consent form.

Families of the DG had already been submitted to an individual interview about the children's development (health, medical history, use of medication, academic, literacy, learning disabilities, and developmental disorders) before the diagnosis process, and the responsibles for the $\mathrm{CG}$ received a printed questionnaire regarding the neuropsychomotor development of the child.

The neuropsychological assessment was conducted individually, either at NANI (DG) or in schools (CG), in an appropriate room. All children participated in three 1 hour and a half sessions.

The neuropsychological assessment was composed by a measure of intelligence (subscales of the Wechsler Intelligence Scale for Children - WISC-III FSIQ- Picture Arrangement, Coding - Part B, Block Design, Picture Completion, Vocabulary, Similarities, Arithmetic and Digit-Span; De Jong et al., 2009; Wechsler, 2002), school performance (School Performance Test - TDE; Stein, 1994), attention (Conner's Continuous Performance Test CCPT; Miranda, Sinnes, Pompéia, \& Bueno, 2008; Spreen $\&$ Strauss, 1998), working memory (Corsi Block-Tapping Test - forward and backward order; Lezak, 1995), semantic memory (Semantic and Phonological Verbal Fluency (FAS; Spreen \& Strauss, 1998), episodic memory (Logical Memory; Wilson, Ivani-Chalian, \& Aldrich, 1991) and
Free Word and Picture Recall Test (Miranda, 2000), cognitive flexibility (Wisconsin Card Sorting Test - WCST; Cunha et al., 2005; Heaton et al., 2005), laterality (Edinburgh Inventory; Britto, 2002), Right-Left Discrimination (Britto, 2002) and visuo-constructive ability (Rey Complex Figures - Figure B (Rey, 1999). The CCPT was conduced only to excluded children with TDAH.

All procedures of the present study were approved by the Ethics Committee of the University (Universidade Federal de São Paulo [UNIFESP] - protocol number $1510 / 05)$.

\section{Statistical Analysis}

Kolmogorov-Smirnov and descriptive statistics was done to confirm Normal distribution. Student's $t$-tests were used for numeric variables and Chi-squared test for the nominal variables.

An Analysis of Covariance was carried out through the General Linear Model (GLM), based on the difference observed in the level of intelligence (FSIQ) between groups. The significance level adopted was of .05

\section{Results}

Demographic characteristics of the sample indicated that no significant differences were observed between the CG and the DG, considering matching variables (i.e., age, gender, school year, and school type). The DG was composed of 39 children ( 27 boys), with a mean age of 10.71 ( \pm 2.29 ) and the CG by 34 children ( 20 boys), with a mean age of $10.62( \pm 1.84)$. The majority of the sample - 58.8\% of the CG and $61.5 \%$ of the DG - attended public schools, distributed between $3^{\text {rd }}$ and $9^{\text {th }}$ grade.

Both groups obtained significant differences in the overall school performance, regarding reading, writing and mathematics subtests (Mann-Whitney test; $p s \leq .001$ ), as well as in the level of intelligence (Student's $t$-test) measured by the Full Scale Intelligence Quotient (FSIQ), Verbal IQ (VIQ) and Performance IQ (PIQ; $p s \leq .001$; Table 1).

To avoid differences in the neuropsychological variables, that could be a reflex of group differences in the level of intelligence, data analysis was conducted with the co-variation of FSIQ. Therefore, results of the neuropsychological variables described below were done using an Analysis of Covariance, through the General Linear Model.

There were significant differences between the CG and DG regarding the following neuropsychological variables: reading, writing, mathematics and overall TDE $(p s \leq .0001)$; Forward and Backward digit spans ( $p s \leq .005)$; animal and fruit fluency $(p s \leq .003)$; Phonological Verbal Fluency (F, A and total score; $p s \leq .05)$; WCST measures (categories completed and total number of cards ( $p s \leq .05$ ); right-left discrimination on self and on other ( $p s \leq .001$, as shown on Tables 1 and 2). 
Table 1

Mean ( \pm standard desviation) with Covariance of Full Scale Intellectual Quocient of Neuropsychological Variables (General Linear Model-GLM)

\begin{tabular}{|c|c|c|c|c|}
\hline & & Control Group & Dyslexia group & GLM \\
\hline & & Mean $\pm S D$ & Mean $\pm S D$ & $p$ \\
\hline \multirow[t]{3}{*}{ Level of Intelligence } & FSIQ & $121.88 \pm 12.21$ & $100.38 \pm 16.51$ & $.001^{*}$ \\
\hline & VIQ & $120.68 \pm 12.72$ & $97.05 \pm 15.31$ & $.001^{*}$ \\
\hline & PIQ & $119.68 \pm 11.98$ & $103.82 \pm 17.11$ & $.001 *$ \\
\hline \multirow[t]{4}{*}{ School Performance } & Reading & $63.33 \pm 2.83$ & $41.31 \pm 2.54$ & $.001^{*}$ \\
\hline & Writing & $30.2 \pm 1.16$ & $10.67 \pm 1.04$ & $.001 *$ \\
\hline & Mathematics & $22.92 \pm 1.35$ & $12.62 \pm 1.21$ & $.001 *$ \\
\hline & Total & $116.32 \pm 4.41$ & $64.34 \pm 3.96$ & $.001 *$ \\
\hline \multirow[t]{4}{*}{ Working Memory } & Forward Digit Span & $4.97 \pm .17$ & $4.14 \pm .16$ & $.002 *$ \\
\hline & Backward Digit Span & $3.76 \pm .16$ & $3.01 \pm .16$ & $.005^{*}$ \\
\hline & Corsi forward order & $5.15 \pm .21$ & $4.91 \pm .2$ & .457 \\
\hline & Corsi backward order & $4.71 \pm .2$ & $4.44 \pm .19$ & .404 \\
\hline \multirow[t]{6}{*}{ Semantic Memory } & Animal Fluency & $15.36 \pm .78$ & $11.61 \pm .75$ & $.003^{*}$ \\
\hline & Fruit Fluency & $12.34 \pm .63$ & $9.26 \pm .61$ & $.003^{*}$ \\
\hline & Letter F Fluency & $8.14 \pm .67$ & $5.7 \pm .65$ & $.025^{*}$ \\
\hline & Letter A Fluency & $7.06 \pm .5$ & $5.36 \pm .48$ & $.034^{*}$ \\
\hline & Letter S Fluency & $6.05 \pm .49$ & $4.89 \pm .48$ & .142 \\
\hline & FAS sum & $21.26 \pm 1.41$ & $15.95 \pm 1.36$ & $.020^{*}$ \\
\hline \multirow[t]{4}{*}{ Episodic Memory } & Immediate Story Memory & $20.07 \pm .89$ & $19.71 \pm .86$ & .796 \\
\hline & Delayed Story Memory & $19.12 \pm .87$ & $18.64 \pm .84$ & .730 \\
\hline & $\begin{array}{l}\text { Recall of Semantically } \\
\text { Unrelated Words }\end{array}$ & $5.05 \pm .23$ & $4.42 \pm .24$ & .096 \\
\hline & $\begin{array}{l}\text { Recall of Semantically } \\
\text { Related Words }\end{array}$ & $4.83 \pm .27$ & $4.34 \pm .28$ & .262 \\
\hline \multirow{3}{*}{$\begin{array}{l}\text { WCST Executive } \\
\text { Function }\end{array}$} & Number of categories & $5.49 \pm .28$ & $4.38 \pm .3$ & $.016^{*}$ \\
\hline & total cards & $104.87 \pm 3.46$ & $116.82 \pm 3.73$ & $.037^{*}$ \\
\hline & fail setting & $0.83 \pm .2$ & $.86 \pm .22$ & .905 \\
\hline \multirow{3}{*}{$\begin{array}{l}\text { Visuo-Constructive } \\
\text { Ability }\end{array}$} & Rey Complex Figure - copy & $27.49 \pm 1.63$ & $20.64 \pm 1.77$ & .082 \\
\hline & $\begin{array}{l}\text { Rey Complex Figure / } \\
\text { immediate memory }\end{array}$ & $13.57 \pm 1.62$ & $10.1 \pm 1.75$ & .188 \\
\hline & $\begin{array}{l}\text { Rey Complex Figure - delayed } \\
\text { memory }\end{array}$ & $12.91 \pm 1.61$ & $9.23 \pm 1.75$ & .161 \\
\hline
\end{tabular}

${ }^{*} p \leq .05$. 
Cruz-Rodrigues, C., Barbosa, T., Toledo-Piza, C. M. J., Miranda, M. C. \& Bueno, O. F. A. (2014). Neuropsychological Characteristics of Dyslexic Children.

Table 2

Performance of Control Group and Dyslexia Group in Laterality and Right-Left Discrimination (General Linear Models) Tests

\begin{tabular}{|c|c|c|c|c|c|}
\hline & & & Control Group & Dyslexia Group & $p$ \\
\hline \multirow[t]{12}{*}{ Laterality (\%) } & \multirow[t]{3}{*}{ Hand } & Right & 82.35 & 92.30 & \multirow[t]{3}{*}{.087} \\
\hline & & Left & 5.88 & 7.69 & \\
\hline & & Both & 11.76 & & \\
\hline & \multirow[t]{2}{*}{ Foot } & Right & 82.35 & 92.10 & \multirow[t]{2}{*}{.212} \\
\hline & & Left & 17.64 & 7.89 & \\
\hline & \multirow[t]{3}{*}{ Ear } & Right & 82.35 & 89.74 & \multirow[t]{3}{*}{.345} \\
\hline & & Left & 17.64 & 7.69 & \\
\hline & & Both & & 2.56 & \\
\hline & \multirow[t]{2}{*}{ Eye } & Right & 76.47 & 86.84 & \multirow[t]{2}{*}{.253} \\
\hline & & Left & 23.52 & 13.15 & \\
\hline & \multirow[t]{2}{*}{ Crossed } & Yes & 32.35 & 18.42 & \multirow[t]{2}{*}{.173} \\
\hline & & No & 67.64 & 81.57 & \\
\hline Right X Left & \multirow[t]{3}{*}{ On self } & Yes & 100 & 67.56 & \multirow[t]{3}{*}{$.001 *$} \\
\hline Discrimination (\%) & & No & 0 & 8.10 & \\
\hline & & Partial & 0 & 24.32 & \\
\hline & \multirow[t]{3}{*}{ On others } & Yes & 76.47 & 24.32 & \multirow[t]{3}{*}{$.001 *$} \\
\hline & & No & 5.88 & 32.43 & \\
\hline & & Partial & 17.64 & 43.24 & \\
\hline
\end{tabular}

${ }^{*} p \leq .05$.

\section{Discussion}

The main purpose of this study was to identify the neuropsychological characteristics of dyslexic children. The main findings indicated differences in the intellectual level (FSIQ, VIQ and PIQ), impairment in executive functions, phonological working memory, semantic memory and right-left discrimination.

These results emphasize that learning and the development of abilities involving reading and writing in children depend on a series of factors, being related to the development of neuropsychological functions, biological/ maturational and psychosocial factors (both family and school-related; Salles \& Parente, 2008). In such way, the similarity of demographic characteristics verified in the pairing of groups (DG and CG), was fundamental in order to investigate of the underlying factors, such as the neuropsychological characteristics, related to dyslexia. Data indicated that the DG presented poorer school performance, when compared to CG in all reading, writing and mathematics subtests. This suggests that in addition to dyslexia, a concomitant impairment was observed in writing and/or mathematics skills. This observation cor- roborates previous findings by Berninger, Nielsen, Abbott, Wijsman, and Raskind (2008).

Although the DG presented an average level of intelligence, their mean overall scores were significantly lower when compared to the CG. Such result was also observed in other studies, such as that by D'Angiulli and Siegel (2003), in which children who present reading and mathematics disorders showed poorer performance in both VIQ and PIQ, when compared to children without a learning disorder, although such measure is even more impaired in dyslexia. In addition, other studies (D'Angiulli \& Siegel, 2003; Ferrer, Shaywitz, Holahan, Marchione, \& Shaywitz, 2010; Ingesson, 2006), like the present one, have found impairment in VIQ and sometimes in PIQ. Longitudinal studies with the dyslexic individuals have shown an even greater difference in the intelligence measures over the years, when compared to fluent readers (D'Angiulli \& Siegel, 2003; Ferrer et al., 2010). However, academic impairment in dyslexia does not seem to be explained by the level of intelligence, since academic impairment persists even when the level of intelligence is co varied.

Previous research has shown that little exposure to print/reading (Griffiths \& Snowling, 2002), a late diagno- 
sis/identification process and the 'continuous cycle system' implemented in Brazilian public schools (Cruz-Rodrigues, Barbosa, Toledo-Piza, \& Mello, 2009), contribute to the lack of academic knowledge, observed in children and directly reflected on their level of intelligence, since the WISC III, used for the assessment of such variable, measures crystallized intelligence, which refers to the ability to recall and use acquired information over a lifetime (Horn, 1965; Schelini, 2006). Therefore, the relatively low results, are influenced by poor education and cultural experiences, which depend on reading. That is, reading less does not only negatively affects reading and writing development, but also negatively influences the development of language and IQ, as described by Arduini et al. (2006) and Ferrer et al. (2010).

Ferrer et al. (2010) suggests that, although performance in reading tests in the initial school years is very low, cognitive abilities (FSIQ) do not present themselves as very poor during such schooling stage; however, these differences increase over the years. In Brazil, there is a shortage of services adopting interdisciplinary assessment for the diagnosis of dyslexia and, consequently, the majority of children are diagnosed at a later stage, which can lead to greater impairment in cognitive development (Cruz-Rodrigues et al., 2009) and to an even larger difficulty in intervention, since other related functions and abilities may also be compromised and affected.

Considering other neuropsychological deficits, results indicated significant differences, in semantic and phonological fluency, WCST measures (total number of cards), right-left discrimination (on self and on others) and phonological working memory. No differences were observed in episodic memory and visuo-constructive abilities.

According to Baddeley's working memory model (WM; 2000), dyslexic children may present impairment in tasks involving the phonological loop ,even though most of these individuals have within average performances in skills that involve the visuo-spatial sketchpad, central executive and/or episodic buffer subcomponents (Kibby \& Cohen, 2008; Kibby et al., 2004). Data obtained in this research confirms findings of Kibby and Cohen (2008) and Kibby et al. (2004), since there was a group difference in the verbal WM tasks (FW and BW digit spans); however, no differences were observed in the visuo-spatial WM tasks (Corsi blocks; De Jong et al., 2009).

Dyslexic children frequently present impairment in verbal/phonological WM tasks, (i.e., those requiring phonological decoding, such as digit repetition, sequences and word lists; Brosnan et al., 2002; Kibby \& Cohen, 2008). Such difficulties in verbal manipulation of information may be related to the predominantly phonological deficit, observed in dyslexia (Ramus et al., 2003; Salles \& Parente, 2006). The verbal/phonological WM, phonological awareness and the level of verbal intelligence (VIQ) may also be involved in language abilities (Kibby, 1999, apud Kibby \& Cohen 2008).
Furthermore, Maehler and Schuchardt (2009) suggest that children with dyslexia and a low IQ present the same working memory impairment as those with an average or above average IQ, reinforcing that differences based on the level of intelligence, observed between groups in this study, may not interfere significantly with the performance of other cognitive functions and the differences actually obtained occur due to LD.

In what refers to semantic memory ability, differences observed between CG and DG have also been found in previous studies by Brosnan et al. (2002), where dislexics showed lower performances in verbal fluency tasks, using letters F and S. Reiter, Tucha, and Lange (2005) analyzed semantic and phonological cues, using letter ' $S$ ' and the animal category, and results corroborated such findings. In similar studies Davidson, Gao, Mason, Winocur, and Anderson (2008), claimed that verbal fluency tasks depends on the development of language and storage capacity, in addition to a good access to the semantic lexicon. Nevertheless, in the present study, both groups did not differ in story recall tasks, as observed by Kibby and Cohen (2008), demonstrating that episodic memory was preserved in the dyslexia group.

While the phonological processing is the predominant deficit associated to dyslexia some researchers have also investigated that these individuals may sometimes present motor impairment, such as difficulty in writing. Therefore, this observation suggests that there can be a motor deficit associated to dyslexia (Ramus et al., 2003; Stoodley \& Stein, 2006). The present research found differences in right-left discrimination tasks, although manual preference, characterized by greater efficiency in the use of a given hand (right or left) for the performance of tasks requiring coordination and speed (Roeder et al., 2008), did not differ between the groups. Such data indicates that the right or left lateral dominance might not be related to dyslexia but, instead, to the ability to discriminate right and left on oneself and on others. According to Diamond (2000), there is evidence that motor abilities are developed along with cognitive functions. Praxical abilities, bi-manual coordination and visuo-motor skills are not fully developed before adolescence and are associated with complex cognitive functions, such as mental representation and mental flexibility. Thus, when cognitive development is affected, impairment of motor functions is frequently observed in some development disorders, suggesting that motor alteration may not only be a sign of development retardation, but a permanent deficit which would also characterize dyslexia.

The assessment of executive functions, more specifically of mental flexibility, analyzed in this study using the number of categories achieved in the WCST, showed that the DG presented a lower number of completed categories when compared to the CG. The same result was observed in a study by Menghini et al. (2010). On the other hand, Reiter et al. (2005) who carried out a study using the Modified Card Sorting Test (MCST), similar to WCST but without 
Cruz-Rodrigues, C., Barbosa, T., Toledo-Piza, C. M. J., Miranda, M. C. \& Bueno, O. F. A. (2014). Neuropsychological Characteristics of Dyslexic Children.

the use of ambiguous cards, did not observe differences between dyslexics and the control group, suggesting that dyslexic children showed impairment in the executive functions, such as planning and problem solving, but not mental flexibility. It is necessary to carry out further studies of executive functions (EF) in dyslexia, which may also lead to the development of new concepts in the treatment in these conditions.

Findings that dyslexia is a complex disorder, associated to heterogeneous deficits, which may lead to difficulties in reading and in other neuropsychological functions serves as a basis for the multiple deficit model of dyslexia, which proposes a multivaried continuous performance characterized by cognitive abilities relating to reading (Menghini et al., 2010; Pennington, 2006; Pennington et al., 2012). These theories post that individual differences found in reading and writing are conceptualized in terms of a multidimensional model, where there is a continuous variation of language components and literacy abilities (Bishop \& Snowling, 2002). Therefore, differences may occur in the underlying cognitive abilities, as well as in the reading development profile. Studies emphasize the relevance of learning about the underlying cognitive mechanisms in the reading and writing process (Barbosa et al., 2009; Bishop \& Snowling, 2002; Capellini \& Ciasca, 2000; Salles \& Parente 2006).

Data obtained in this study corroborates with the idea of heterogeneity and multiple cognitive domains involved (Fletcher, Coulter, Reschly, \& Vaughn, 2004; Hendriksen et al., 2007; Kavale \& Forness, 2000) in learning disorders and countless factors which influence learning (Kaefer, 2006). It also reinforces the importance of an interdisciplinary investigation (Barbosa et al., 2009; Bishop \& Snowling, 2002; Capellini \& Ciasca, 2000; Salles \& Parente, 2006) and a case by case analysis (Salles \& Parente, 2008), due to the variations showed in the previously mentioned neuropsychological characteristics. These two investigations provide the promotion of programs favoring the global development of neuropsychological functions involved in the acquisition of learning, as well as the compensation of reading and writing problems.

It is also important to point out the limitations of scientific studies in this area and the specificity health care and education professionals must have when analyzing variables involved in learning, which are influenced by countless factors.

\section{References}

American Psychiatric Association. (2003). DSM - IV - TR- Manual diagnóstico e estatístico de transtornos mentais (4. ed., C. Dornelles, Trad.). Porto Alegre, RS: Artmed.

Arduini, R. G., Capellini, S. A., \& Ciasca A. M. (2006). Estudo comparativo das avaliações neuropsicológicas e de neuroimagem em crianças com dislexia. Arquivos de Neuro-Psiquiatria, 64(2B), 369-375.

Baddeley, A. (2000). The episodic buffer: A new component of working memory? Trends Cognitive Sciences, 4, 417-423.
Barbosa, T., Miranda, M. C., Santos, R. F., \& Bueno, O. F. A. (2009). Phonological working memory, phonological awereness and language in literacy difficulties in Brazilian children. Reading \& Writing, 22, 201-218.

Berninger, V. W., Nielsen, K. H., Abbott, R. D., Wijsman, E., \& Raskind, W. (2008). Writing problems in developmental dyslexia: Under-recognized and under-treated. Journal of School Psychology, 46(1), 1-21.

Bishop, D. V. M. (2006). Dyslexia: What's the problem? Developmental Science, 9(3), 256-257.

Bishop, D. V. M., \& Adams, C. (1990). A prospective study of the relationship between specific language impairment, phonological disorders and reading retardation. Journal of Child Psychology and Psychiatry, 31(7), 1027-1050.

Bishop, D. V. M., \& Snowling, M. J. (2002). Predictors of exception word and nonword reading in dyslexic children: The severity hypothesis. Journal of Experimental Psychology, 94(1), 34-43.

Britto, N. O. B. (2002). BTN: Bateria de testes neuropsicológicos: Manual. Rio de Janeiro, RJ: Entreletras.

Brosnan, M., Demetre, J., Hamill, S., Robson, K., Shepherd, H., \& Cody, G. (2002). Executive functioning in adults and children with developmental dyslexia. Neuropsychologia, 40, 2144-2155.

Capellini, S. A., \& Ciasca, S. M. (2000). Avaliação da consciência fonológica em crianças com distúrbio específico de leitura e escrita e distúrbio de aprendizagem. Temas sobre Desenvolvimento, 8(48), 17-23.

Catts, H. W. (1993). The relationship between speech-language impairments and reading disabilities Journal of Speech, Language, and Hearing Research, 36, 948-958.

Ciasca, S. M. (2003). Distúrbios de aprendizagem: Proposta de avaliação interdisciplinar. São Paulo, SP: Casa do Psicólogo.

Cunha, J. A., Trentini, C. M., Argimon, I. L., Oliveira, M. S., Werlang, B. G., \& Prieb, R. G. (2005). Adaptação e padronização brasileira do Teste Wisconsin de Classificação de Cartas. São Paulo, SP: Casa do Psicólogo.

Cruz-Rodrigues, C., Barbosa, T., Toledo-Piza, C. M. J., \& Mello, C. B. (2009). Implementação e caracterização de um serviço de assistência e pesquisa em distúrbios de aprendizagem. In T. Barbosa, C. Cruz-Rodrigues, C. B. Mello, S. A. Capellini, R. Mousinho, \& L. M. Alves, Temas em dislexia (Cap. 12). São Paulo, SP: Artes Médicas.

D'Angiulli, A. S., \& Siegel, L. S. (2003). Cognitive functioning as measure by the WISC-R: Do children with learning disabilities have disticntive patterns of performance? Journal of Learning Disabilities, 36(1), 48-58.

Davidson, P. S. R., Gao, F. Q., Mason, W. P., Winocur, G., \& Anderson, N. D. (2008). Verbal fluency, trail making, and Wisconsin card sorting test performance following right frontal lobe tumor resection. Journal of Clinical Experimental Neuropsychology, 30(1), 18-32.

De Jong, C. G. W., Van De Voorde, S., Roeyers, H., Raymaekers, R., Oosterlaan, J., \& Sergeant, J. (2009). How distinctive are ADHD and RD? Results of a double dissociation study. Journal of Abnormal Child Psychology, 37, 1007-1017.

Diamond, A. (2000). Close interrelation of motor development and cognitive development and of the cerebellum and prefrontal cortex. Child Development, 71(1), 44-56.

Ferrer, E., Shaywitz, B. A., Holahan, J. M., Marchione, K., \& Shaywitz, S. E. (2010). Uncoupling of reading and IQ over time: Empirical evidence for a definition of dyslexia. Psychological Science, 21(1), 93-101. 
Fletcher, J. M., Coulter, W. A., Reschly, D. J., \& Vaughn, S (2004). Alternative approaches to the definition and identification of learning disabilities: Some questions and answers. Annals of Dyslexia, 54(2), 304-331.

Griffiths, Y. M., \& Snowling, M. J. (2002). Predictors of exception word and nonword reading in dyslexic children: The severity hypothesis. Journal of Education Psychology, 94(1), 34-43.

Heaton, R. K., Chelune, G. J., Talley, L. T., Kay, G. G., Gary, C., \& Curtiss, G. (2005). Teste Wisconsin de Classificação de Cartas: Manual (ed. rev. e ampl., J. A. Cunha, C. M. Trentini, I. L. Argimon, M. S Oliveira, B. G. Werlang, \& R. G. Prieb, adaptação e padronização brasileira). São Paulo, SP: Casa do Psicólogo.

Hendriksen, J. G., Keulers, E. H., Feron, F. J., Wassenberg, R., Jolles, J., \& Vles, J. S. (2007). Subtypes of learning disabilities: Neuropsychological and behavioural functioning of 495 children referred for multidisciplinary assessment. European Child \& Adolescent Psychiatry, 16(8), 517-524.

Horn, J. L. (1965). Fluid and crystallized intelligence: A factor analytic and developmental study of the structure among primary mental abilities (Unpublished doctoral dissertation). University of Illinois, Champaign, USA.

Ingesson, S. G. (2006). Stability of IQ measures in teenagers and young adults with developmental dyslexia. Dyslexia, $12,81-95$

Kaefer, H. (2006). Aprendizagem normal - Semiologia psicológica. In N. Rotta, L. Telleche-Ohlweiler, \& R. S. Riesgo, Transtornos da aprendizagem: Abordagem neurológica e multidisciplinar (pp. 87-102). Porto Alegre, RS: Artmed.

Kavale, K. A., \& Forness, S. R. (2000). What definitions of learning disability say and don't say: A critical analysis. Journal of Learning Disabilities, 3(3), 239-256.

Kibby, M. Y., \& Cohen, M. J. (2008). Memory functioning in children with reading disabilities and/or attention deficit/ hyperactivity disorder: A clinical investigation of their working memory and long-term memory functioning. Child Neuropsychology, 31, 1-22.

Kibby, M. Y., Marks, W., Morgan, S., \& Long, C. J. (2004). Specific impairment in developmental reading disabilities: A working memory approach. Journal of Learning Disabilities, 37, 349-363.

Lezak, M. D. (1995). Neuropsychological assessment ( $3^{\text {rd }}$ ed.). New York: Oxford University Press.

Maehler, C., \& Schuchardt, K. (2009). Working memory functioning in children with learning disabilities: Does intelligence make a difference? Journal of Intellectual Disabilities Research, 53(1), 3-10.

Maehler, C., Schuchardt, K., \& Hasselhorn, M. (2008). Working memory deficits in children with specific learning disorders. Journal of Learning Disabilities, 41(6), 514-523.

Menghini, D., Finzi, A., Benassi, M., Bolzani, R., Facoetti, A., Giovagnoli, S., ...Vicari, S. (2010). Different underlying neurocognitive deficits in developmental dyslexia: A comparative study. Neuropsychologia, 48, 863-872.

Miranda, M. C. (2000). Recordação livre de palavras e figuras em crianças pré-escolares (Dissertação de mestrado, Escola Paulista de Medicina, Universidade Federal de São Paulo, SP, Brasil).

Miranda, M. C., Sinnes, E. G., Pompéia, S., \& Bueno, O. F. A. (2008). A comparative study of performance on the Conners' Continuous Performance Test between Brazilian and North American children. Journal of Attention Disorders, 11(5), 588-598.
Pennington, B. F. (2006). From single to multiple deficit models of developmental disorders. Cognition, 101, 385-413.

Pennington, B. F., Santerre-Lemmon, L., Rosenberg, J., MacDonald, B., Boada, R., Friend, A., ...Olson, R. K. (2012). Individual prediction of dyslexia by single versus multiple deficit models. Journal of Abnormal Psychology, 121(1), 212-224.

Pestun, M. S. V., Ciasca, S., \& Gonçalves, V. M. G. (2002). A importância da equipe interdisciplinar no diagnóstico de dislexia do desenvolvimento. Arquivos de Neuropsiquiatria, 60(2A), 328-332.

Ramus, F., Rosen, S, Dakin, S. C., Day, B. L., Castellote, J. M., White, S., \& Frith, U. (2003). Theories of developmental dyslexia: Insights from a multiple case study of dyslexic adults. Brain, 26(4), 841-865.

Reiter, A., Tucha, O., \& Lange, K. W. (2005). Executive functions in children with dyslexia. Dyslexia, 11, 116-131.

Rey, A. (1999). Teste de cópia e de reprodução de memória de figuras geométricas complexas: Manual (M. da S. Oliveira, adaptação brasileira). São Paulo, SP: Casa do Psicólogo.

Roeder, M. B., Mahone, M. E., Larson, J. G., Mostofsky, S. H., Cutting, L. E., Goldberg, M. C., \& Denckla, M. B. (2008). Left-right differences on timed motor examination in children. Child Neuropsychology, 14(3), 249-262.

Salles, J. F., \& Parente, M. A. M. P. (2006). Funções neuropsicológicas em crianças com dificuldades de leitura e escrita. Psicologia, Teoria e Pesquisa, 22(2), 153-162.

Salles, J., \& Parente, M. A. M. P. (2008). Variabilidade no desempenho em tarefas neuropsicológicas entre crianças de $2^{\mathrm{a}}$ série com dificuldades de leitura e escrita. Arquivos Brasileiros de Psicologia, 60(1), 32-44.

Sally, E., \& Shaywitz, M. D. (1998). Dyslexia. The New England Journal of Medicine, 29(5), 307-312.

Santos, M. T. M., \& Navas, A. L. G. P. (2002). Distúrbios de leitura e escrita - Teoria e prática. São Paulo, SP: Manole.

Schelini, P. W. (2006). Teoria das inteligências fluida e cristalizada: Início e evolução. Estudos de Psicologia (Natal), 11(3), 323-332.

Spreen, O., \& Strauss, E. (1998). A compendium of neuropsychological tests. Administrations, norms, and commentary ( $2^{\text {nd }}$ ed.) New York: Orford University Press.

Stein, L. M. (1994). Teste de desempenho escolar - TDE. São Paulo, SP: Casa do Psicólogo.

Stoodley, C. J., \& Stein, J. F. (2006). A processing speed deficit in dyslexic adults? Evidence from a peg-moving task. Neuroscience Letters, 399, 264-267.

Wechsler, D. (2002). WISC-III: Escala de Inteligência Wechsler para Crianças: Manual (3. ed., V. L. M. de Figueiredo, adaptação e padronização brasileira). São Paulo, SP: Casa do Psicólogo.

Wilson, B. A., Ivani-Chalian, R., \& Aldrich F. (1991). The Rivermead Behavioral Memory Tests for children aged 5 to 10-years. Sullfock, UK: Thames Vallery Test Company. 